\title{
Effects of two sources of Mexican oregano oil on performance, blood profile, carcass variables, and meat of broilers
}

\section{Ramón Silva-Vázquez¹, Lorenzo Antonio Duran-Meléndez², Carlos Alberto Hernández-Martínez², Juanita Guadalupe Gutiérrez-Soto ${ }^{3}$, Michael E. Hume ${ }^{4}$, Gerardo Méndez-Zamora ${ }^{3 *}$ iD}

\author{
1 Instituto Tecnologico de Parral, Hidalgo del Parral, Chihuahua, Mexico. \\ 2 Universidad Autonoma de Chihuahua, Facultad de Zootecnia y Ecologia, Chihuahua, Chihuahua, Mexico. \\ ${ }^{3}$ Universidad Autonoma de Nuevo Leon, Facultad de Agronomia, General Escobedo, Nuevo Leon, Mexico. \\ ${ }^{4}$ U.S. Department of Agriculture, Food and Feed Safety Research Unit, Southern Plains Agricultural Research Center, Agricultural Research \\ Service, College Station, Texas, USA.
}

\begin{abstract}
The current study was conducted to investigate the effects of Mexican oregano essential oil (MOO) extracts from Lippia berlandieri Schauer (LBS) and Poliomintha longiflora Gray (PLG) on performance, blood profiles, carcass variables, and meat composition of broilers at slaugther. A total of 360 one-day-old Ross broilers were randomly distributed into four dietary treatments with six replicate pens per treatment and 15 birds per pen. The dietary treatments were: a basal diet (control), control $+0.40 \mathrm{~g}$ of LBS $/ \mathrm{kg}$ of feed, control $+0.40 \mathrm{~g}$ of PLG/ $\mathrm{kg}$, and control $+0.40 \mathrm{~g}$ of LBS $/ \mathrm{kg}+0.40 \mathrm{~g}$ of $\mathrm{PLG} / \mathrm{kg}$. Results showed that linear, quadratic, and cubic effects of days were significant in the performance variables of broilers. The treatments with LBS and PLG maintained the broiler body weight without increasing feed intake and water intake when compared with the control group. Broilers given LBS+PLG and PLG had increased blood leukocytes, lymphocytes, lowdensity lipoprotein, and hot carcass yields. In meat composition, treatments with PLG and LBS+PLG presented similar breast protein content compared with the control treatment. Supplementation with these two MOO exhibits positive effects on broiler performance, blood profiles, carcass traits, and meat composition. These two MOO may be promising feed supplements as growth promoters and enhancers of meat quality in broiler production.
\end{abstract}

Key Words: Lippia berlandieri Schauer, meat quality, Mexican oregano, performance, Poliomintha longiflora Gray

\section{Introduction}

Resistance of pathogenic bacteria to antibiotics used in broiler production is widely known. For this reason, natural alternatives to antibiotics are being pursued and studied in poultry production. Oregano leaves and oregano essential oils (OEO) as phytogenic feed ingredients exhibit properties such as growth promotion, natural antibiotics, and improved meat quality in chickens (Hong et al., 2012). Several species falling under the common name oregano are found in the genera Origanum and Thymus, native to Europe, and Lippia and Poliomintha, originating from the arid Central and North America. The most popular forms under the common name Mexican oregano are Lippia

Received: July 25, 2017

Accepted: March 8, 2018

*Corresponding author: mezage@hotmail.com

Copyright (C) 2018 Sociedade Brasileira de Zootecnia. This is an Open Access article distributed under the terms of the Creative Commons Attribution License (http://creativecommons.org/licenses/by/4.0/), which permits unrestricted use, distribution, and reproduction in any medium, provided the original work is properly cited. berlandieri Schauer and Poliomintha longiflora Gray (Rivero-Cruz et al., 2011). Lippia berlandieri Schauer is a common shrub found in arid regions of northern Central America, Mexico, and the southwestern United States, while Poliomintha longiflora Gray is a spindly shrub restricted to arid north-central Mexico, as well as in Haiti. The dried foliage and inflorescences of both Mexican varieties are used as condiments and as treatment for respiratory and digestive diseases (Rivero-Cruz et al., 2011). The main constituents of essential oils from Mexican oregano include carvacrol, thymol, $\beta$-myrcene, $\alpha$-terpinene, $\gamma$-terpinene, $p$-cymene, and ceneol (Vazquez and Dunford, 2005; SilvaVazquez et al., 2017).

A number of researchers have evaluated performance and meat quality of broilers given plant extracts (Akbarian et al., 2013; Sharifi et al., 2013; Cho et al., 2014; Park et al., 2014; Starčević et al., 2015) and OEO (Hong et al., 2012; Khattak et al., 2014; Kırkpınar et al., 2014; Küçükyılmaz et al., 2014; Ghazi et al., 2015; Silva-Vázquez et al., 2015; Sun et al., 2015; Ghazanfari et al., 2015; Hashemipour et al., 2016; Peng et al., 2016; Méndez-Zamora et al., 2017; Reyer et al. 2017; Chowdhury et al., 2018), demonstrating their 
influence on feed intake, growth enhancement, blood parameters, and meat quality. Silva-Vazquez et al. (2017) indicated that Greek (Origanum vulgare L. ssp. Hirtum), Turkish (Origanum onites L.), Spanish (Thymus capitatus L.), and Mexican oreganos (Lippia graveolens HBK, Lippia berlandieri Schauer, Lippia palmeri Watson, and Poliominthaa longiflora Gray) are important essential oil-producing species. In general, extracts of Origanum vulgare L. and Origanum onites L., or their mixtures have been studied extensively in broilers. In contrast, comparatively little research has been reported on the effects of Mexican oregano essential oils (MOO) on broiler performance, blood parameters, and meat quality (Méndez-Zamora et al., 2015a,b; Silva-Vázquez et al., 2015; Méndez-Zamora et al., 2017). Silva-Vazquez et al. (2017) proposed that oregano oil and its fractions can be viable alternatives to the synthetic antioxidants widely used in foods and animal feed. Accordingly, it is important to expand research on these very promising MOO for use in poultry production.

The objective of the current study was to investigate the effects of two Mexican oregano essential oils, Lippia berlandieri Schauer and Poliomintha longiflora Gray, on broiler performance, blood parameters, carcass variables, and meat quality.

\section{Material and Methods}

The research was conducted in Chihuahua City, Chihuahua, Mexico, located between $28^{\circ} 38^{\prime} \mathrm{N}$ and $106^{\circ} 04^{\prime} \mathrm{W}$ parallels, at an altitude of $1,440 \mathrm{~m}$, with a mean annual temperature $20{ }^{\circ} \mathrm{C}$, annual precipitation between 200 $600 \mathrm{~mm}$, and in a temperate dry climate (INEGI, 2017). Research on broilers was conducted in accordance with animal use committee guidelines (case no. NOM-062ZOO-1999).

A total of 360 one-day-old Ross 308 mixed-sex broiler chicks $(42.68 \pm 1.38 \mathrm{~g})$ were randomly assigned to four treatments (diets) in which essential oils from two Mexican oreganos, Lippia berlandieri Schauer (LBS) and Poliomintha longiflora Gray (PLG), were evaluated: control diet, without MOO; control $+0.40 \mathrm{~g}$ of LBS $/ \mathrm{kg}$ of feed; control $+0.40 \mathrm{~g}$ of PLG $/ \mathrm{kg}$; and control $+0.40 \mathrm{~g}$ of $\mathrm{LBS} / \mathrm{kg}+0.40 \mathrm{~g}$ of PLG $/ \mathrm{kg}$. Each treatment consisted of six replicate floor pens $(1.25 \times 1.25 \times 0.70 \mathrm{~m})$, with fresh wood shavings, and 15 broilers in each pen. Mexican oregano essential oils used in the study were purchased from Natural Solutions Company SMI (Jimenez, Chihuahua, Mexico). The MOO composition (Table 1) was obtained by gas chromatography (PerkinElmer Clarus 600 and SQ8
GC/MS; PerkinElmer Inc., Waltham, MA, USA) according to the method of Dunford and Silva (2005).

The starter diet for broilers of $0-21$ days of age and finisher diet for broilers of 22-42 days of age were formulated according to NRC (1994) and as used by Silva-Vázquez et al. (2015). The MOO were mixed with canola oil as carrier and added to the basal control diet as previously indicated (Silva-Vázquez et al., 2015). Feed and water were provided ad libitum. Husbandry practices were applied according to Roofchaee et al. (2011) and Silva-Vázquez et al. (2015). The temperature was set at $34{ }^{\circ} \mathrm{C}$ on the first day, followed by $32{ }^{\circ} \mathrm{C}$ over the remainder of the first week, then was reduced by $3{ }^{\circ} \mathrm{C}$ per week until it reached $23{ }^{\circ} \mathrm{C}$. The relative humidity fluctuated between 25 and $75 \%$. Lighting was provided $22 \mathrm{~h} /$ day.

Broiler initial weight (IW; g) was determined at the beginning of the experiment. Broiler body weight (BW), feed intake [FI; (intake of feed per week/number of broilers per pen)], water intake [WI; (intake of water per week/ number of broilers per pen)], average daily gain [ADG; $\left(\mathrm{BW}_{\text {current }}-\mathrm{BW}_{\text {previous }}\right) /$ day], and feed conversion ratio (FCR; $\mathrm{BW} / \mathrm{FI}$ ) were determined at 7, 14, 21, 28, 35, and 42 days. The offered and rejected feed weights were recorded.

Blood sampling and blood characterization were performed according to the method of Hong et al. (2012) with modifications. Blood samples of one randomly selected broiler per pen ( $\mathrm{n}=6$ broilers per treatment) were obtained from the wing vein at 42 days. Immediately after collection, blood was set at $4{ }^{\circ} \mathrm{C}$, then serum was separated by centrifugation at $1,500 \times \mathrm{g}$ for $15 \mathrm{~min}$. Cholesterol (CHOL), triglycerides (TG), high-density lipoprotein (HDL), lowdensity lipoprotein (LDL), and very low-density lipoprotein (VLDL) were measured with a biochemical analyzer (KONTROLab ${ }^{\circledR}$ EKEM, Roma, Italy) using commercial reagents (Stanbio Laboratory, Boerne, TX, USA). Complete blood cell count was determined according the methods of Medway et al. (1969) and Maxine (1984).

Table 1 - Essential oil composition of Mexican oregano

\begin{tabular}{lcc}
\hline \multirow{2}{*}{ Component $(\mathrm{vol} \%)^{1}$} & \multicolumn{2}{c}{ Mexican oregano } \\
\cline { 2 - 3 } & LBS & PLG \\
\hline Carvacrol & 60.02 & 13.89 \\
Thymol & 3.96 & 28.49 \\
Cineole 1,8 & 23.63 & 0.56 \\
p-cymene & 9.57 & 5.53 \\
$\gamma$-terpinene & 0.11 & 17.85 \\
Menthol & ND & 0.80 \\
Eugenol & ND & 0.62 \\
Others & 2.71 & 32.26
\end{tabular}

LBS - Lippia berlandieri Schauer; PLG - Poliomintha longiflora Gray; ND - not detected.

${ }^{1}$ Components were analyzed by GC/MS Clarus SQ 8 (PerkinElmer $\left.{ }^{\circledR}\right)$. 
The slaughter process was carried out according to the Official Mexican Standard (NOM-033-SAG/ZOO, 2014) and the method of Méndez-Zamora et al. (2015a). Twentyfour randomly selected broilers from each treatment (four broilers per pen), were slaughtered at 42 days (electrically stunned at $70 \mathrm{~V}$, killed by cervical dislocation). Slaughter weight (SW) and hot carcass weight (HCW) were recorded, and hot carcass yield [HCY; $(\mathrm{HCW} / \mathrm{SW}) \times 100]$ was calculated. The cold carcass weight (CCW) was taken $24 \mathrm{~h}$ post mortem to determine the cold carcass yield [CCY; $(\mathrm{CCW} / \mathrm{SW}) \times 100]$.

Twelve carcasses were randomly selected from each treatment (two carcasses per replicate). Cut pieces of each carcass were made to record the weights of legs, thighs, hips, backs, wings, and breasts for each broiler. These weights were expressed as a percentage of SW and were considered as piece variables $[\%$ piece $=($ piece weight $/ \mathrm{SW})$ $\times$ 100]. Similarly, cooking loss (CL) was evaluated for twelve carcass pieces according to the method applied by López et al. (2011) and was determined through the formula $\% \mathrm{CL}=[($ raw weight piece - cooked weight piece $) /$ raw weight piece] $\times 100$.

The chemical composition analysis of the breasts $(\mathrm{n}=12)$ and legs $(\mathrm{n}=12)$ was performed in triplicate $24 \mathrm{~h}$ post mortem according to methods of the AOAC (1998). Moisture was measured by weight loss after 12-h drying at $100{ }^{\circ} \mathrm{C}$ in a forced-air oven (code 950.46). Protein contents were determined by the Kjeldahl method (code 992.15). Fat content was measured by the Soxhlet extraction solvent method (code 985.15). Ash weight was measured after exposing the muscle for $4 \mathrm{~h}$ at $400{ }^{\circ} \mathrm{C}$ in a muffle furnace (code 920.153).

Linear, quadratic, and cubic effects were analyzed to examine model fits of dependent variables, and the GLM multivariate ANOVA (MANOVA) procedure of SAS (Statistical Analysis System, version 9) was used to determine global effects of observed differences for all performance measures, fitting the treatments and days as the fixed effects, as well as their interactions. Production variables were analyzed using the MIXED procedure of SAS and the following statistical model (1) (Wang and Goonewardene, 2004):

$$
\mathrm{y}_{i j k}=\mu+\mathrm{T}_{i}+\delta_{j}+(\mathrm{T} \delta)_{i j}+\Phi_{k(i j)}+\lambda+\varepsilon_{i j k}
$$

in which $\mathrm{y}_{i j k}=$ production variables measured during the experiment, $\mu=$ general mean, $\mathrm{T}_{i}=$ effect of the $i$-th treatment (control, LBS, PLG, and LBS+PLG), $\delta_{j}=$ effect of the $j$-th day of fattening $(7,14,21,28,35$, and 42 days $),(\mathrm{T} \delta)_{i j}=$ fixed effect of the interaction between $i$-th treatment and $j$-th day of fattening, $\Phi_{k(i j)}=$ nested effect of the $i$-th treatment in each pen where the broilers remained for the $j$-th day of fattening, $\lambda=$ effect of the covariate IW, and $\varepsilon_{i j k}=$ random error normally distributed with mean zero and variance $\sigma^{2}$ $\left[\varepsilon_{i j k} \sim \mathrm{N}\left(0, \sigma^{2}\right)\right]$. Slaughter, carcass cut pieces, cooking loss, and dissected and chemical composition (moisture, protein, fat, and ash) results were analyzed with the GLM procedure and the following statistical model (2):

$$
\mathrm{y}_{i j}=\mu+\mathrm{T}_{i}+\lambda+\varepsilon_{i j}
$$

in which $\mathrm{y}_{i j}=$ variables evaluated, $\mu=$ general mean, $\mathrm{T}_{i}=$ effect of the $i$-th treatment (control, LBS, PLG and LBS+PLG); $\lambda=$ effect of the covariate IW, and $\varepsilon_{i j}=$ random error normally distributed with mean zero and variance $\sigma^{2}\left[\varepsilon_{i j} \sim \mathrm{N}\left(0, \sigma^{2}\right)\right]$. A significance level of $\mathrm{P}<0.05$ was used to detect significant statistical difference, and when the P-value was less than 0.05 , the treatment means were compared and analyzed using the instruction Adjust $=$ Tukey.

\section{Results}

Linear effects of treatments were found for BW and FI (Table 2). Quadratic and cubic effects were not seen in BW, FI, WI, ADG, and FCR. Linear, quadratic, and cubic effects of days were significant for broiler performance variables. In global effects (MANOVA), the fixed effects and interaction showed differences $(\mathrm{P}<0.05)$ for all performance variables.

Body weight was different by day (7-42 days) for each treatment, with $\mathrm{BW}$ being higher $(\mathrm{P}<0.05)$ at 42 days (Table 3). Broilers given the control diet presented the highest $(\mathrm{P}<0.05)$ weight at 42 days while those given LBS presented the lowest $(\mathrm{P}<0.05)$. At $14,21,28,35$, and 42 days, weights for groups fed PLG and LBS+PLG were not different from the control groups, although BW was $0.15 \mathrm{~kg}$ less for these groups compared with the control. The effect of treatments on FI was different $(\mathrm{P}<0.05)$ at $7,14,21$, and 35 days; in general, FI was higher in the control and lower in LBS-fed group. Feed intake for groups fed PLG and LBS+PLG was not different $(\mathrm{P}>0.05)$ from control at 14 and 21 days, while groups fed LBS and PLG were not different $(\mathrm{P}>0.05)$ from control at 35 days. Throughout the experiment (0-42 days), FI was different $(\mathrm{P}<0.05)$ between treatments with FI highest in control and lowest in LBS-fed broilers, although groups fed PLG and LBS+PLG were not different $(\mathrm{P}>0.05)$ from control and LBS groups. The effect of treatment on water intake (WI) was significant $(\mathrm{P}<0.05)$ at 14,21 , and 28 days, but there were no significant differences $(\mathrm{P}>0.05)$ by treatment at 7 , 35 , and 42 days. Specifically, WI for LBS-fed group at 14, 21 , and 28 days exhibited the lowest values $(\mathrm{P}<0.05)$. From 
0 to 42 days, control, PLG, and LBS+PLG broilers had the highest $(\mathrm{P}=0.045)$ total water intake, while LBS-fed broilers had the lowest intake.

Production efficiency was affected $(\mathrm{P}<0.05)$ over time and between treatments (Table 4). Average daily gain (ADG) was different $(\mathrm{P}<0.05)$ among treatments at $7,14,21$, and 28 days, but was not different $(\mathrm{P}>0.05)$ among treatments at 35 and 42 days. Specifically, treatments affected $(\mathrm{P}<0.05)$
ADG in the period from 7 to 28 days, in which LBS was generally signicantly $(\mathrm{P}<0.05)$ lower and ADG for control group was slightly higher than that for PLG and LBS+PLG groups. Total ADG from 0 to 42 days for control broilers was higher $(\mathrm{P}<0.05)$ than that for LBS broilers and showed improvement over broilers given PLG and LBS+PLG. Within treatment, FCR changed $(\mathrm{P}<0.05)$ over time with FCR at 7 days being the lowest and highest at 42 days.

Table 2 - Global effects on performance in broilers fed diets supplemented with dietary Mexican oregano essential oil extracts

\begin{tabular}{|c|c|c|c|c|c|}
\hline \multirow{2}{*}{ Statistic effect } & \multicolumn{5}{|c|}{ Dependent variable } \\
\hline & BW & FI & WI & ADG & FCR \\
\hline \multicolumn{6}{|c|}{ Treatments } \\
\hline Linear & 0.0364 & 0.0187 & 0.9852 & 0.1775 & 0.7726 \\
\hline Quadratic & 0.0886 & 0.2380 & 0.8800 & 0.4031 & 0.6224 \\
\hline Cubic & 0.4626 & 0.4395 & 0.8552 & 0.5678 & 0.6053 \\
\hline \multicolumn{6}{|c|}{ Days } \\
\hline Linear & $<0.0001$ & $<0.0001$ & $<0.0001$ & $<0.0001$ & $<0.0001$ \\
\hline Quadratic & $<0.0001$ & $<0.0001$ & $<0.0001$ & $<0.0001$ & $<0.0001$ \\
\hline Cubic & $<0.0001$ & $<0.0001$ & $<0.0001$ & $<0.0001$ & $<0.0001$ \\
\hline \multicolumn{6}{|c|}{ Coefficient of determination $\left(\mathrm{R}^{2}\right)$} \\
\hline Linear & 0.9763 & 0.9584 & 0.8823 & 0.7823 & 0.8372 \\
\hline Quadratic & 0.9783 & 0.8746 & 0.7579 & 0.6469 & 0.8964 \\
\hline Cubic & 0.9246 & 0.7708 & 0.6295 & 0.5192 & 0.8795 \\
\hline \multicolumn{6}{|c|}{ Multivariate ANOVA (MANOVA; Wilks lambda) } \\
\hline Treatments $\left(\mathrm{T}_{\mathrm{i}}\right)$ & \multicolumn{5}{|c|}{$<0.0001$} \\
\hline Days $\left(\delta_{\mathrm{j}}\right)$ & \multicolumn{5}{|c|}{$<0.0001$} \\
\hline$(\mathrm{T} \delta)_{\mathrm{ij}}$ & \multicolumn{5}{|c|}{$<0.0001$} \\
\hline
\end{tabular}

BW - body weight; FI - feed intake; WI - water intake; ADG - average daily gain; FCR - feed conversion ratio.

Table 3 - Performance parameters of broilers fed diets supplemented with dietary Mexican oregano essential oil extracts

\begin{tabular}{|c|c|c|c|c|c|c|c|}
\hline \multirow{2}{*}{ Trait/Treatment ${ }^{1}$} & \multicolumn{7}{|c|}{ Days } \\
\hline & 7 & 14 & 21 & 28 & 35 & \multicolumn{2}{|c|}{42} \\
\hline \multicolumn{8}{|c|}{ BW (g) } \\
\hline Control & $181.50 \mathrm{aF}$ & $465.33 \mathrm{aE}$ & $891.50 \mathrm{aD}$ & $1,478.17 \mathrm{aC}$ & $2,067.17 \mathrm{aB}$ & \multicolumn{2}{|c|}{$2,641.50 \mathrm{aA}$} \\
\hline LBS & $170.00 \mathrm{bF}$ & $384.83 \mathrm{bE}$ & $737.16 \mathrm{bD}$ & $1,286.83 b C$ & $1,878.50 \mathrm{bB}$ & \multicolumn{2}{|c|}{$2,423.17 \mathrm{bA}$} \\
\hline PLG & $159.94 \mathrm{bF}$ & $438.17 \mathrm{aE}$ & $879.83 \mathrm{aD}$ & $1,437.17 \mathrm{aC}$ & $1,983.50 \mathrm{abB}$ & \multicolumn{2}{|c|}{$2,500.50 \mathrm{abA}$} \\
\hline $\mathrm{LBS}+\mathrm{PLG}$ & $159.83 \mathrm{bF}$ & $429.50 \mathrm{abE}$ & $851.50 \mathrm{aD}$ & $1,422 \cdot 17 \mathrm{aC}$ & $1,952.50 \mathrm{abB}$ & \multicolumn{2}{|c|}{$2,501.83 \mathrm{abA}$} \\
\hline SEM & 4.48 & 13.33 & 17.65 & 31.39 & 35.26 & \multicolumn{2}{|c|}{53.44} \\
\hline \multirow[t]{2}{*}{ P-value } & 0.0014 & 0.0086 & $<0.0001$ & 0.0055 & 0.0145 & \multicolumn{2}{|c|}{0.0237} \\
\hline & 7 & 14 & 21 & 28 & 35 & 42 & $0-42$ \\
\hline \multicolumn{8}{|c|}{$\mathrm{FI}(\mathrm{g})$} \\
\hline Control & $150.00 \mathrm{aE}$ & $406.67 \mathrm{aD}$ & $678.33 \mathrm{aC}$ & $980.00 \mathrm{~B}$ & $1,033.33 \mathrm{aB}$ & $1,225.00 \mathrm{~A}$ & $4,471.95 \mathrm{a}$ \\
\hline LBS & $140.00 \mathrm{bF}$ & $308.33 \mathrm{bE}$ & $550.00 \mathrm{bD}$ & $896.67 \mathrm{C}$ & $1,023.33 \mathrm{abB}$ & $1,176.67 \mathrm{~A}$ & $4,082.51 b$ \\
\hline PLG & $126.67 \mathrm{bF}$ & $381.67 \mathrm{aE}$ & $631.67 \mathrm{aD}$ & $918.33 \mathrm{C}$ & $1,025.00 \mathrm{abB}$ & $1,205.00 \mathrm{~A}$ & 4,288.03ab \\
\hline $\mathrm{LBS}+\mathrm{PLG}$ & $133.33 \mathrm{bE}$ & $393.33 \mathrm{aD}$ & $631.67 \mathrm{aC}$ & $930.00 \mathrm{~B}$ & $936.67 \mathrm{bB}$ & $1,170.00 \mathrm{~A}$ & $4,190.18 \mathrm{ab}$ \\
\hline SEM & 4.15 & 11.94 & 14.50 & 26.50 & 24.26 & 28.51 & 74.99 \\
\hline P-value & 0.0031 & 0.0003 & $<0.0001$ & 0.1864 & 0.0286 & 0.4480 & 0.0103 \\
\hline \multicolumn{8}{|c|}{ WI (g) } \\
\hline Control & 403.33D & $971.67 \mathrm{aC}$ & $1,695.00 \mathrm{aB}$ & $2,253.33 \mathrm{aA}$ & $2,398.33 \mathrm{~A}$ & $2,395.00 \mathrm{~A}$ & $10,115.43 a$ \\
\hline LBS & $420.33 \mathrm{E}$ & $703.33 \mathrm{bD}$ & $1,318.33 b C$ & $1,955.00 \mathrm{bB}$ & $2,361.67 \mathrm{~A}$ & $2,288.33 \mathrm{~A}$ & $9,220.73 b$ \\
\hline PLG & 383.33D & $923.33 \mathrm{aC}$ & $1,658.33 \mathrm{abB}$ & $2,285.00 \mathrm{aA}$ & $2,435.00 \mathrm{~A}$ & $2,476.67 \mathrm{~A}$ & $10,162.45 \mathrm{a}$ \\
\hline $\mathrm{LBS}+\mathrm{PLG}$ & $375.00 \mathrm{D}$ & $881.67 \mathrm{aC}$ & $1,518.33 \mathrm{abB}$ & $2,333.33 \mathrm{aA}$ & $2,390.00 \mathrm{~A}$ & $2,461.67 \mathrm{~A}$ & $9,958.11 \mathrm{a}$ \\
\hline SEM & 12.66 & 26.54 & 94.11 & 55.25 & 74.79 & 67.24 & 244.07 \\
\hline P-value & 0.2180 & $<0.0001$ & 0.0371 & 0.0017 & 0.8984 & 0.5794 & 0.0450 \\
\hline
\end{tabular}

BW - body weight; FI - feed intake; WI - water intake; SEM - standard error of the mean.

${ }^{1}$ Control diet: without Mexican oregano essential oils; LBS: control $+0.40 \mathrm{~g}$ of Lippia berlandieri Schauer (LBS)/kg of feed; PLG: control $+0.40 \mathrm{~g}$ of Poliomintha longiflora Gray $(\mathrm{PLG}) / \mathrm{kg}$; LBS+PLG: control $+0.40 \mathrm{~g}$ of LBS $/ \mathrm{kg}+0.40 \mathrm{~g}$ of PLG $/ \mathrm{kg}$.

$\mathrm{a}, \mathrm{b}$ - Means $(\mathrm{n}=6$ replicate $)$ in columns and with different letters are significantly different $(\mathrm{P}<0.05)$.

A-F - Means $(n=6$ replicate $)$ in rows and with different letters are significantly different $(\mathrm{P}<0.05)$. 
The FCR between treatments was different $(\mathrm{P}<0.05)$ at 14 , 28 , and 35 days, but did not differ $(\mathrm{P}>0.05)$ at days 7,21 , and 42 (Table 4). Broilers given LBS presented maximum efficiency at 14 days and the lowest at 28 and 35 days, while PLG-fed broilers had the highest $(\mathrm{P}<0.05) \mathrm{FCR}$ at 28 days and the lowest $(\mathrm{P}<0.05)$ at 14 days, and the $\mathrm{LBS}+\mathrm{PLG}$ group was the best $(\mathrm{P}<0.05)$ at 35 days. Throughout the experiment (0-42 days), FCR was not different $(\mathrm{P}>0.05)$ among treatments.

Hematological biometry (Table 5) for leukocytes, lymphocytes, hematocrit, and hemoglobin concentrations were influenced by treatments $(\mathrm{P}<0.05)$. Leukocytes and lymphocytes were higher $(\mathrm{P}<0.05)$ in broilers fed LBS + PLG and PLG than in the congrol group. The hematocrit volume percentage $(\% \mathrm{vol})$ and hemoglobin content in control broilers were the highest $(\mathrm{P}<0.05)$ and lowest $(\mathrm{P}<0.05)$ in the LBS group. Of the lipid components, only LDL was affected by the treatment, with PLG and LBS + PLG broilers presenting the highest values $(\mathrm{P}<0.05)$ and control the lowest $(\mathrm{P}<0.05)$. There were no differences ( $P>0.05)$ among treatment groups for the remaining blood components.

Table 4 - Production efficiency of broilers fed diets supplemented with dietary Mexican oregano essential oil extracts

\begin{tabular}{|c|c|c|c|c|c|c|c|}
\hline \multirow{2}{*}{ Trait/Treatment ${ }^{1}$} & \multicolumn{7}{|c|}{ Days } \\
\hline & 7 & 14 & 21 & 28 & 35 & 42 & $0-42$ \\
\hline \multicolumn{8}{|c|}{$\mathrm{ADG}(\mathrm{g})$} \\
\hline Control & $19.98 \mathrm{aD}$ & $34.59 \mathrm{aC}$ & $54.95 \mathrm{aB}$ & $77.86 \mathrm{aA}$ & $78.21 \mathrm{~A}$ & $76.12 \mathrm{~A}$ & $61.88 \mathrm{a}$ \\
\hline LBS & $16.98 \mathrm{bC}$ & $28.11 \mathrm{bC}$ & $46.52 \mathrm{bB}$ & $62.05 \mathrm{bA}$ & $79.38 \mathrm{~A}$ & $74.18 \mathrm{~A}$ & $56.69 b$ \\
\hline PLG & $16.40 \mathrm{bD}$ & $33.00 \mathrm{abC}$ & $56.48 \mathrm{aB}$ & $73.00 \mathrm{aA}$ & $71.48 \mathrm{~A}$ & $67.23 \mathrm{~A}$ & $58.50 \mathrm{ab}$ \\
\hline $\mathrm{LBS}+\mathrm{PLG}$ & $16.04 \mathrm{bD}$ & $31.72 \mathrm{abC}$ & $53.51 \mathrm{aB}$ & $74.71 \mathrm{aA}$ & $69.02 \mathrm{~A}$ & $71.66 \mathrm{~A}$ & $58.54 \mathrm{ab}$ \\
\hline SEM & 0.63 & 1.59 & 1.86 & 3.12 & 2.55 & 5.69 & 1.37 \\
\hline P-value & 0.0018 & 0.0231 & 0.0041 & 0.0074 & 0.0634 & 0.5215 & 0.0496 \\
\hline \multicolumn{8}{|c|}{ FCR } \\
\hline Control & $1.21 \mathrm{ED}$ & $1.14 \mathrm{abE}$ & $1.32 \mathrm{D}$ & $1.51 \mathrm{abC}$ & $2.01 \mathrm{abB}$ & $2.16 \mathrm{~A}$ & 1.69 \\
\hline LBS & $1.22 \mathrm{E}$ & $1.26 \mathrm{aDE}$ & $1.35 \mathrm{CD}$ & $1.44 b C$ & $1.84 \mathrm{bB}$ & $2.07 \mathrm{~A}$ & 1.69 \\
\hline PLG & $1.27 \mathrm{E}$ & $1.14 \mathrm{bE}$ & $1.39 \mathrm{D}$ & $1.56 \mathrm{aC}$ & $1.94 \mathrm{abB}$ & $2.08 \mathrm{~A}$ & 1.72 \\
\hline $\mathrm{LBS}+\mathrm{PLG}$ & $1.21 \mathrm{CD}$ & 1.09abD & $1.35 \mathrm{C}$ & $1.53 \mathrm{abB}$ & $2.09 \mathrm{aA}$ & $2.14 \mathrm{~A}$ & 1.68 \\
\hline SEM & 0.02 & 0.03 & 0.02 & 0.03 & 0.05 & 0.05 & 0.04 \\
\hline P-value & 0.2295 & 0.0119 & 0.1490 & 0.0383 & 0.0283 & 0.4859 & 0.8352 \\
\hline
\end{tabular}

ADG - average daily gain; FCR - feed conversion ratio; SEM - standard error of the mean.

${ }^{1}$ Control diet: without Mexican oregano essential oils; LBS: control + $0.40 \mathrm{~g}$ of Lippia berlandieri Schauer (LBS)/kg of feed; PLG: control + 0.40 g of Poliomintha longiflora Gray $(\mathrm{PLG}) / \mathrm{kg}$; LBS+PLG: control $+0.40 \mathrm{~g}$ of $\mathrm{LBS} / \mathrm{kg}+0.40 \mathrm{~g}$ of PLG $/ \mathrm{kg}$.

$\mathrm{a}, \mathrm{b}-$ Means $(\mathrm{n}=6$ replicate $)$ in columns and with different letters are significantly different $(\mathrm{P}<0.05)$.

A-E - Means $(n=6$ replicate) in rows and with different letters are significantly different $(\mathrm{P}<0.05)$.

Table 5 - Blood profile of broilers fed diets supplemented with dietary Mexican oregano essential oil extracts at 42 days

\begin{tabular}{|c|c|c|c|c|c|c|}
\hline \multirow{2}{*}{ Parameter } & \multicolumn{4}{|c|}{ Treatment $^{1}$} & \multirow{2}{*}{ SEM } & \multirow{2}{*}{ P-value } \\
\hline & Control & LBS & PLG & LBS+PLG & & \\
\hline \multicolumn{7}{|l|}{ Hematological biometry } \\
\hline Leukocytes $\left(10^{3} / \mu \mathrm{L}\right)$ & $17.7 \mathrm{~b}$ & $21.00 \mathrm{ab}$ & $22.88 \mathrm{a}$ & $25.32 \mathrm{a}$ & 1.18 & 0.001 \\
\hline $\mathrm{MCH}(\mathrm{pg})$ & 50.82 & 52.22 & 52.55 & 52.58 & 1.64 & 0.854 \\
\hline Heterophile $\left(10^{3} / \mu \mathrm{L}\right)$ & 5.80 & 6.32 & 7.02 & 6.34 & 0.86 & 0.800 \\
\hline Lymphocytes $\left(10^{3} / \mu \mathrm{L}\right)$ & $10.64 b$ & $13.75 \mathrm{ab}$ & $14.83 \mathrm{a}$ & $16.91 \mathrm{a}$ & 0.91 & 0.001 \\
\hline Erythrocytes $\left(10^{6} / \mu \mathrm{L}\right)$ & 2.78 & 2.39 & 2.48 & 2.64 & 0.11 & 0.114 \\
\hline Hematocrit (vol\%) & $41.83 \mathrm{a}$ & $37.33 b$ & $38.83 \mathrm{ab}$ & $41.50 \mathrm{ab}$ & 1.06 & 0.019 \\
\hline Hemoglobin (g/dL) & $13.94 \mathrm{a}$ & $12.45 b$ & $12.95 \mathrm{ab}$ & $13.83 \mathrm{ab}$ & 0.35 & 0.019 \\
\hline \multicolumn{7}{|c|}{ Lipids and lipoprotein profile (mg/dL) } \\
\hline Cholesterol & 126.17 & 121.50 & 126.33 & 136.17 & 5.93 & 0.378 \\
\hline
\end{tabular}

MCV - mean corpuscular volume; MCH - mean corpuscular hemoglobin; HDL - high-density lipoprotein; LDL - low-density lipoprotein; VLDL - very low-density lipoprotein; SEM - standard error of the mean.

${ }^{1}$ Control diet: without Mexican oregano essential oils; LBS: control + $0.40 \mathrm{~g}$ of Lippia berlandieri Schauer (LBS)/kg of feed; PLG: control + 0.40 g of Poliomintha longiflora Gray $(\mathrm{PLG}) / \mathrm{kg}$; LBS+PLG: control $+0.40 \mathrm{~g}$ of $\mathrm{LBS} / \mathrm{kg}+0.40 \mathrm{~g}$ of PLG $/ \mathrm{kg}$.

$\mathrm{a}, \mathrm{b}$ - Means $(\mathrm{n}=6$ birds $)$ in rows and with different letters are significantly different $(\mathrm{P}<0.05)$. 
Slaughter variables, carcass piece yields, and cooking loss were influenced by treatment (Table 6). The LBS-fed group had the lowest $(\mathrm{P}<0.05) \mathrm{HCY}$ (Table 6). While HCY of control was only slightly higher, it was not different $(\mathrm{P}>0.05)$ from that for broilers fed PLG and LBS+PLG. Cold carcass yields were not affected $(\mathrm{P}>0.05)$ by treatment. In carcass piece yields, leg and hip pieces were influenced $(\mathrm{P}<0.05)$ by treatment with LBS presenting the best leg yield, while LBS+PLG and control presenting the lowest. Hips from control broilers had the highest yield $(\mathrm{P}<0.05)$, without differing $(\mathrm{P}>0.05)$ from yields of broilers fed LBS and LBS+PLG, and PLG-fed broilers had the lowest $(\mathrm{P}<0.05)$. Thighs, backs, wings, and breasts were not influenced $(\mathrm{P}>0.05)$ by the treatment. On the other hand, hip and back cooking loss (Table 6) were affected $(\mathrm{P}<0.05)$ by treatment. Hip CL was highest $(\mathrm{P}<0.05)$ in $\mathrm{LBS}$-fed broilers, while back CL was highest $(\mathrm{P}<0.05)$ for control and LBS-fed broilers. Legs, thighs, wings, and breasts were not influenced $(\mathrm{P}>0.05)$ by treatment with Mexican oregano oil.

Protein and fat composition of breast meat were influenced $(\mathrm{P}<0.05)$ by treatment (Table 7$)$, but leg composition was not affected $(\mathrm{P}>0.05)$. Protein content in breast meat of control broilers was highest $(\mathrm{P}<0.05)$ and the lowest $(\mathrm{P}<0.05)$ in LB-fed broilers. However, values of PLG and LBS+PLG treatments were not different from

Table 6 - Influence of Mexican oregano essential oil extracts on slaugther variables, carcass piece yields, and cooking loss of broilers at 42 days

\begin{tabular}{|c|c|c|c|c|c|c|}
\hline \multirow{2}{*}{ Variable } & \multicolumn{4}{|c|}{ Treatment $^{1}$} & \multirow{2}{*}{ SEM } & \multirow{2}{*}{ P-value } \\
\hline & Control & LBS & PLG & $\mathrm{LBS}+\mathrm{PLG}$ & & \\
\hline SW (kg) & $2.83 \mathrm{a}$ & $2.43 \mathrm{c}$ & $2.72 \mathrm{ab}$ & $2.62 b$ & 0.04 & 0.001 \\
\hline $\operatorname{HCY}(\%)$ & $73.41 \mathrm{a}$ & $70.16 \mathrm{~b}$ & $72.98 \mathrm{a}$ & $72.42 \mathrm{a}$ & 0.40 & 0.001 \\
\hline CCY (\%) & 72.67 & 72.45 & 73.25 & 73.50 & 0.41 & 0.234 \\
\hline \multicolumn{7}{|c|}{ Piece yield $(\%)^{2}$} \\
\hline Leg & $11.32 b$ & $12.26 \mathrm{a}$ & $11.69 \mathrm{ab}$ & $11.34 b$ & 0.26 & 0.050 \\
\hline Thigh & 10.26 & 10.42 & 10.12 & 9.81 & 0.23 & 0.292 \\
\hline Hip & $8.40 \mathrm{a}$ & 7.99ab & $7.55 b$ & $7.82 \mathrm{ab}$ & 0.22 & 0.060 \\
\hline Back & 6.07 & 5.61 & 5.53 & 5.81 & 0.16 & 0.101 \\
\hline Wings & 8.00 & 8.11 & 7.90 & 7.84 & 0.22 & 0.830 \\
\hline Breast & 29.48 & 29.32 & 29.59 & 30.34 & 0.59 & 0.622 \\
\hline \multicolumn{7}{|c|}{ Cooking loss (\%) } \\
\hline Leg & 10.30 & 10.83 & 11.71 & 10.84 & 1.35 & 0.905 \\
\hline Thigh & 7.80 & 6.73 & 6.69 & 8.96 & 1.53 & 0.690 \\
\hline Hip & $8.59 b$ & $15.35 \mathrm{a}$ & $10.66 \mathrm{~b}$ & $10.80 \mathrm{~b}$ & 1.14 & 0.003 \\
\hline Back & $13.60 \mathrm{a}$ & $13.60 \mathrm{a}$ & $9.34 b$ & $9.31 b$ & 1.34 & 0.038 \\
\hline Wings & 6.42 & 5.62 & 4.03 & 5.80 & 1.19 & 0.544 \\
\hline Breast & 11.65 & 11.61 & 10.23 & 9.60 & 0.91 & 0.314 \\
\hline
\end{tabular}

SW - slaughter weight; HCY - hot carcass yield; CCY - cold carcass yield; SEM - standard error of the mean.

${ }^{1}$ Control diet: without Mexican oregano essential oils; LBS: control $+0.40 \mathrm{~g}$ of Lippia berlandieri Schauer (LBS)/kg of feed; PLG: control + 0.40 g of Poliomintha longiflora Gray $(\mathrm{PLG}) / \mathrm{kg} ; \mathrm{LBS}+\mathrm{PLG}$ : control $+0.40 \mathrm{~g}$ of $\mathrm{LBS} / \mathrm{kg}+0.40 \mathrm{~g}$ of PLG $/ \mathrm{kg}$

$2 \%=($ piece or carcass weight $/ \mathrm{SW}) \times 100$.

a-c - Means ( $\mathrm{n}=24$ carcasses to slaughter; $\mathrm{n}=12$ carcass to piece yield and cooking loss) in rows and with different letters are significantly different $(\mathrm{P}<0.05)$.

Table 7 - Influence of Mexican oregano oils on chemical composition of breast and leg meat

\begin{tabular}{|c|c|c|c|c|c|c|}
\hline \multirow{2}{*}{ Piece composition } & \multicolumn{4}{|c|}{ Treatment $^{1}$} & \multirow{2}{*}{ SEM } & \multirow{2}{*}{ P-value } \\
\hline & Control & LBS & PLG & LBS+PLG & & \\
\hline \multicolumn{7}{|l|}{$\overline{\text { Breast }(\%)^{2}}$} \\
\hline Protein & $23.06 \mathrm{a}$ & $22.33 b$ & $22.85 \mathrm{ab}$ & $22.85 \mathrm{ab}$ & 0.14 & 0.006 \\
\hline Fat & $1.00 \mathrm{~b}$ & $1.06 \mathrm{ab}$ & $1.04 \mathrm{ab}$ & $1.13 \mathrm{a}$ & 0.03 & 0.050 \\
\hline Ash & 1.15 & 1.19 & 1.20 & 1.15 & 0.03 & 0.408 \\
\hline Protein & 20.26 & 20.17 & 20.06 & 20.33 & 0.12 & 0.439 \\
\hline Fat & 1.62 & 1.67 & 1.65 & 1.71 & 0.03 & 0.338 \\
\hline Ash & 1.07 & 1.09 & 1.10 & 1.06 & 0.02 & 0.501 \\
\hline
\end{tabular}

SEM - standard error of the mean; SW - slaughter weight.

${ }^{1}$ Control diet: without Mexican oregano essential oils; LBS: control $+0.40 \mathrm{~g}$ of Lippia berlandieri Schauer (LBS)/kg of feed; PLG: control + $0.40 \mathrm{~g}$ of Poliomintha longiflora Gray $(\mathrm{PLG}) / \mathrm{kg}$; LBS + PLG: control $+0.40 \mathrm{~g}$ of $\mathrm{LBS} / \mathrm{kg}+0.40 \mathrm{~g}$ of PLG $/ \mathrm{kg}$.

$2 \%=($ piece or carcass weight $/ \mathrm{SW}) \times 100$.

$\mathrm{a}-\mathrm{b}$ - Means $(\mathrm{n}=12$; two breasts per replicate) in rows and with different letters are significantly different $(\mathrm{P}<0.05)$. 
control and from LBS. Fat content was highest $(\mathrm{P}<0.05)$ in breast meat from broilers fed LBS+PLG and lowest $(\mathrm{P}<0.05)$ in meat from control broilers. Breast meat fat content in LBS- and PLG-fed broilers was not different $(\mathrm{P}>0.05)$ from control and LBS+PLG broilers.

\section{Discussion}

In the current study, linear effects of treatments for broiler BW and FI were similar to those reported by Hashemipour et al. (2013), Giannenas et al. (2014), Hossain et al. (2014), and Alba et al. (2015), using natural compounds to enhance broiler performance. The $\mathrm{R}^{2}$ values showed that the best analysis for treatments is the linear model, while the linear, quadratic, and cubic models were useful for indicating broiler performance over time.

The effects found in the current study with $0.4 \mathrm{~g}$ of $\mathrm{MOO} / \mathrm{kg}$ of feed coincided with results from recent studies with plant extracts in diets on broiler performance and feed efficiency (Cho et al., 2014; Khattak et al., 2014; Park et al., 2014; Ghazi et al., 2015; Sun et al., 2015; Hashemipour et al., 2016; Peng et al., 2016; Chowdhury et al., 2018). Specifically, Reyer et al. (2017) revealed improved growth performance in all groups fed the phytogenic additives $[25.0 \mathrm{mg}$ of an essential oil blend (star anise, rosemary, thyme, and oregano) $/ \mathrm{kg}$ of feed, $46.0 \mathrm{mg}$ of a Quillaja saponin blend $/ \mathrm{kg}$, or a combination of both preparations (essential oils + saponins)] compared with control broilers from 8 to 21 days; our results at 21 days with PLG and LBS+PLG in feed was not different from the control group. At 42 days of the current study, body weight was maintained by MOO treatments, results similar to those of Kırkpınar et al. (2011), Cho et al. (2014), and Mohiti-Asli and Ghanaatparast-Rashti (2015), who found that 300 and $500 \mathrm{ppm}$ of $\mathrm{OEO}$ and $250 \mathrm{mg} / \mathrm{kg}$ of feed of phytogenic (oregano, carvacrol, cinnamaldehyde) supplements maintained broiler weight over 22-35 days and 42 days, respectively. These changes may be correlated with the levels of feed additives used in those diets in association with their chemical compositions. Contrary to our results, Hashemipour et al. (2016) obtained improved growth performance in broilers using 300 and $600 \mathrm{mg}$ of $\mathrm{OEO} / \mathrm{kg}$ of feed. For our study, results indicated that MOO supplementation did not change FI and WI throughout the experiment. In the current study, essential oil extract from Poliomintha longiflora (PLG) presented FI similar to the control group, and similar to results of Khattak et al. (2014), who demonstrated no change in broiler FI when evaluating mixtures of essential oils. Similar results were obtained by Küçükyılmaz et al. (2014) in BW and FI in the period of
0-42 days when evaluating $48 \mathrm{mg}$ of a dietary OEO mixture (oregano, sage, myrtle, fennel, and citrus peel)/kg of feed.

Throughout the experimental period in the current study, ADG was influenced by supplementation of MOO, but FCR was not different among treatment groups. It may be that MOO odors prepare the gastrointestinal tract for feed reception and stimulate digestive secretions (saliva, salivary amylase, lipase, amylase, and proteases) and gut motility (Brenes and Roura, 2010), and, as a consequence, improve ADG. These effects agree with Ghazi et al. (2015), Sun et al. (2015), Hashemipour et al. (2016), and Peng et al. (2016) when evaluating $60,250,300$, and $600 \mathrm{mg}$ of $\mathrm{OEO} / \mathrm{kg}$ of feed, and 100 and $200 \mathrm{mg}$ of a mixture of thymol plus carvacrol $/ \mathrm{kg}$, respectively. Similarly, these results on production efficiency and variations in the results could be due to the composition and inclusion level of extracts. Furthermore, it is important to consider that diets formulated with OEO improve digestibility, regulate the microbiota of the intestinal ecosystem, and stimulate the secretion of endogenous digestive enzymes (Ghazi et al., 2015), and thymol+carvacrol could have positive effects on broiler performance (Hashemipour et al., 2016). The maximum efficiency at 14 days exhibed in LBS-fed broilers and 28 days in the PLG-fed broilers could be explained by results demostrated in the study carried out by Reyer et al. (2017), who indicated that differences in the relative expression of intestinal transporters such as PepT1 (SLC15A1), GLUT2, and EAAT3 (SLC1A1) affect body weight and feed conversion efficiency in broilers. Analysis by Reyer et al. (2017) at the transcriptional level in Caco-2 cells validated these findings. Furthermore, those authors observed significant increases in membrane recruitment of SGLT1 and PEPT1 after the addition of essential oils and saponins and postulated that increases in the apparent ileal digestibility of nutrients could be explained by the interaction of tested feed additives with the epithelial function of the intestine. These mechanims of action may have occured with MOO tested in the current study. Such results may be overall benefits of phytogenic feed additives in terms of the metabolic usage of macronutrients provided by evidence at the transcriptional level by consistent alterations of lipid and carbohydrate metabolism (Reyer et al., 2017).

Few studies have reported results on blood and lipid profiles in broilers given OEO (Hong et al., 2012; Ghazi et al., 2015; Méndez-Zamora et al., 2017). However, effects on blood parameters in the current study with MOO could be of interest to other researchers, in which LDL was highest in PLG- and LBPL-treated broilers. Compared with results from the current study, Ghazi et al. (2015) found increased blood triglyceride and cholesterol levels 
with their evaluation of $250 \mathrm{mg}$ of oregano oil $/ \mathrm{kg}$ of diet, while Méndez-Zamora et al. (2017) found that $400 \mathrm{mg}$ of MOO $/ \mathrm{kg}$ of feed increased broiler blood HDL and LDL levels. In addition, Park et al. (2014), using extracts from three plants, Saposhnikovia divaricata, Lonicera japonica, and Chelidonium majus, found increases in white blood cells, red blood cells, lymphocytes, hemoglobin, and hematocrit. Likewise, other studies found blood parameter effects following treatment with OEO, anise, and powered peel citrus (Hong et al., 2012), extracts from Mentha spicata (Nanekarani et al., 2012), medicinal plants (Cuminum cyminum, Mentha piperita, Achillea millefolium, Teucrium polium (Sharifi et al., 2013), and coriander essential oil (Ghazanfari et al., 2015). In constrast, Méndez-Zamora et al. (2017) found no effect on blood biometric parameters with $0.40 \mathrm{~g}$ of $\mathrm{OEO} / \mathrm{kg}$ of diet; however, those studies did obtain slightly increased levels of white blood cells, erythrocytes, and hemoglobin. Similar results were obtained in the current study, in which increased levels of leukocytes, lymphocytes, hematocrit, and hemoglobin were found with MOO as a feed supplement. The results from MéndezZamora et al. (2017) and the current study demonstrated that oregano essential oils and Mexican oregano oils, as feed supplements, could be used to improve broiler health; particularly, the MOO plant extracts, PLG-thymol, and LBScarvacrol could have intrinsic biological effects on broiler physiology and metabolism (Méndez-Zamora et al., 2017).

In slaughter variables, Méndez-Zamora et al. (2015a) found results similar to those of the current study; however, carcass yields were higher in the current study. MéndezZamora et al. (2015a) suggested that OEO stimulated digestibility, enhancing nutrient absorption, and broiler body antioxidative stability could be improved by essential oils (Zhai et al., 2018). Khattak et al. (2014) found similar carcass yields to those from the LBS treatment at $400 \mathrm{mg} / \mathrm{kg}$ of diet when they used a mixture of essential oils $(15,30$, 45 , and $60 \mathrm{mg} / \mathrm{kg}$ ), obtaining differences between the control and $15 \mathrm{mg} / \mathrm{kg}$ treatment. Results from those studies and the current study with MOO indicated that the OEO could influence slaughter variables. In addition, diets supplemented with MOO in the current study improved carcass pieces compared with the control group. In contrast, Küçükyılmaz et al. (2014) found no differences in carcass yield, thighs, breasts, and wings when evaluating $28.8 \mathrm{mg}$ of carvacrol $/ \mathrm{kg}$ of feed over 81 days, but their results were higher than those of the current study. Kirkpinar et al. (2014) found no influence on carcass yield, breasts, and thighs when evaluating 150 and $300 \mathrm{mg}$ of $\mathrm{OEO} / \mathrm{kg}$ in diets. Few studies have examined the effect of essential oils on cut piece yields and cooking loss. However, Méndez-Zamora et al. (2015a) stated that components of oregano oil could reduce the bone weight and increase lean meat yields with applications of high levels $(0.40 \mathrm{~g} / \mathrm{kg})$ of extract in broiler diets. This observation may explain leg and hip piece yields in LBS and PLG treatments. Furthermore, this observation may explain differences in carcass pieces when a thermic treatment was applied, in which hip and back cooking loss were affected by the LBS treatment.

Broiler breast protein and fat content were influenced by MOO. In contrast, Hong et al. (2012) and Kırkpınar et al. (2014) found no treatment differences for breast meat chemical compositions. This discrepancy could indicate that levels above $300 \mathrm{mg}$ of OEO/ $\mathrm{kg}$ of feed do influence protein and fat content. Likewise, leg composition in the current study was similar to results obtained by Hong et al. (2012) and Kırkpınar et al. (2014). Otherwise, Starčević et al. (2015) obtained effects of breast and leg meat on protein and fat content, with the effects of thymol $(200 \mathrm{mg} / \mathrm{kg})$, tannic, and gallic acids $(5 \mathrm{~g} / \mathrm{kg})$ similar to those of LBS, PLG, and LBPL treatments. It is possible that OEO affects lipid content, deposited as fat in muscle tissue. MéndezZamora et al. (2015b) found differences in fat composition of breast meat in broilers given 0.40 and $0.80 \mathrm{~g}$ of OEO $(60 \%$ carvacrol and $40 \%$ thymol $) / \mathrm{kg}$ of feed, indicating that high doses of OEO could increase fat and protein content. Similar increases in these components were obtained in the LBS+PLG treatment $(0.80 \mathrm{~g} / \mathrm{kg}$ total combination), which indicated that $\mathrm{OEO}$ combinations improve the protein and fat content of breast meat.

\section{Conclusions}

The evaluation of two sources of Mexican oregano oils at $0.40 \mathrm{~g} / \mathrm{kg}$ in the diet exhibit positive effects on broiler performance, blood profiles, carcass traits, and meat composition. Mexican oregano oils improve leukocyte and lymphocyte concentrations without altering hemoglobin and hematocrit. Mexican oregano essential oils may be promising alternatives to synthetic antioxidants and performance enhancers in broiler production and as enhancers of carcass meat quality.

\section{Acknowledgments}

This research was supported by Facultad de Zootecnia y Ecologia, Universidad Autonoma de Chihuahua, which provided the installations and some ingredients of diets. Likewise, we acknowledge the Facultad de Agronomia, Universidad Autonoma de Nuevo Leon, for funding this manuscript. 


\section{References}

Akbarian, A.; Golian, A.; Kermanshahi, H.; Farhoosh, R.; Raji, A. R.; De Smet, S. and Michiels, J. 2013. Growth performance and gut health parameters of finishing broilers supplemented with plant extracts and exposed to daily increased temperature. Spanish Journal of Agricultural Research 11:109-119.

Alba, M.; Esmaeilipour, O. and Mirmahmoudi, R. 2015. Effects of Withania coagulans fruit powder and vitamin $\mathrm{C}$ on growth performance and some blood components in heat stressed broiler chickens. Livestock Science 173:64-68.

AOAC - Association of Official Analytical Chemists. 1998. Official methods of analysis. 15th ed. AOAC International, Maryland, USA.

Brenes, A. and Roura, E. 2010. Essential oils in poultry nutrition: Main effects and modes of action. Animal Feed Science and Technology 158:1-14.

Cho, J. H.; Kim, I. H. and Kim, I. J. 2014. Effects of phytogenic feed additive on growth performance, digestibility, blood metabolites, intestinal microbiota, meat color and relative organ weight after oral challenge with clostridium perfringens in broilers. Livestock Science 160:82-88.

Chowdhury, S.; Prasad Mandal, G. and Kumar Patra, A. 2018. Different essential oils in diets of chickens: 1 . Growth performance, nutrient utilisation, nitrogen excretion, carcass traits and chemical composition of meat. Animal Feed Science and Technology 236:86-97.

Dunford, N. T. and Silva, V. R. 2005. Effect of water stress on plant growth and thymol and carvacrol concentrations in Mexican oregano grown under controlled conditions. Journal of Applied Horticulture 7:20-22.

Ghazanfari, S.; Mohammadi, Z. and Adib Moradi, M. 2015. Effects of coriander essential oil on the performance, blood characteristics, intestinal microbiota and histological of broilers. Brazilian Journal of Poultry Science 17:419-426.

Ghazi, S.; Amjadian, T. and Norouzi, S. 2015. Single and combined effects of vitamin $\mathrm{C}$ and oregano essential oil in diet, on growth performance, and blood parameters of broiler chicks reared under heat stress condition. International Journal of Biometeorology 59:1019-1024.

Giannenas, I.; Papaneophytou, C. P.; Tsalie, E.; Pappas, I.; Triantafillou, E.; Tontis, D. and Kontopidis, G. A. 2014. Dietary supplementation of benzoic acid and essential oil compounds affects buffering capacity of the feeds, performance of turkey poults and their antioxidant status, $\mathrm{pH}$ in the digestive tract, intestinal microbiota and morphology. Asian Australasian Journal of Animal Science 2:225-236.

Hashemipour, H.; Kermanshahi, H.; Golian, A. and Veldkamp, T. 2013. Effect of thymol and carvacrol feed supplementation on performance, antioxidant enzyme activities, fatty acid composition, digestive enzyme activities, and immune response in broiler chickens. Poultry Science 92:2059-2069.

Hashemipour, H.; Khaksar, V.; Rubio, L.A.; Veldkamp, T. and van Krimpen, M. M. 2016. Effect of feed supplementation with a thymol plus carvacrol mixture, in combination or not with an NSPdegrading enzyme, on productive and physiological parameters of broilers fed on wheat-based diets. Animal Feed Science and Technology 211:117-131.

Hong, J. C.; Steiner, T.; Aufy, A. and Lien, T. F. 2012. Effects of supplemental essential oil on growth performance, lipid metabolites and immunity, intestinal characteristics, microbiota and carcass traits in broilers. Livestock Science 137:219-225.

Hossain, M. M.; Lee, S. I. and Kim, I. H. 2014. Effect of dietary Korean aged garlic extract by Leukonostoc citreum SK2556 on production, hematological status, meat quality, relative organ weight, targeted Escherichia coli colony and excreta gas emission in broilers. Animal Feed Science and Technology 198:333-340.

INEGI - Instituto Nacional de Estadística y Geografía. 2017. México en Cifras: Información Nacional por Entidad Federativa y Municipios. Available at: <http://www.beta.inegi.org.mx/app/ areasgeograficas/\#>. Accessed on: March 18, 2017.

Khattak, F.; Ronchi A.; Castelli, P. and Sparks, N. 2014. Effects of natural blend of essential oil on growth performance, blood biochemistry, cecal morphology, and carcass quality of broiler chickens. Poultry Science 93:132-137.

Kırkpınar, F.; Ünlü, H. B. and Özdemir, G. 2011. Effects of oregano and garlic essential oils on performance, carcase, organ and blood characteristics and intestinal microflora of broilers. Livestock Science 137:219-225.

Kırkpınar, F.; Ünlü, H. B.; Serdaroğlu, M. and Turp, G. Y. 2014. Effects of dietary oregano and garlic essential oils on carcass characteristics, meat composition, colour, $\mathrm{pH}$ and sensory quality of broiler meat. British Poultry Science 55:157-166.

Küçükyılmaz, K.; Bozkurt, M.; Çınar, M.; Çatlı, A. U.; Bintaş, E. and Erkek, R. 2014. The effects of an organic rearing system and dietary supplementation of an essential oil mixture on performance and meat yield of slow-growing broilers in two seasons. South African Journal of Animal Science 44:360-370.

López, K. P.; Schilling, M. and Corzo, A. 2011. Broiler genetic strain and sex effects on meat characteristics. Poultry Science 90:1105-1111.

Maxine, N. B. 1984. Manual de patología clínica veterinaria. Limusa, Mexico, D. F. 421p.

Medway, W.; Prier, J. E. and Wilkinson, J. S., 1969. A textbook of veterinary clinical pathology. Williams \& Wilkins Co, Baltimore, Inglaterra. $522 \mathrm{p}$.

Méndez-Zamora, G.; García-Macías, J. A.; Durán-Meléndez, L. A.; Herman-Lara, E.; Santellano-Estrada, E. and Silva-Vazquez, R. 2015a. Aceite esencial de orégano (Lippia berlandieri Schauer) en variables de calidad de la canal de pollo. Ecosistemas y Recursos Agropecuarios 2:41-51.

Méndez-Zamora, G.; García-Macías, J. A.; Santellano-Estrada, E.; Durán-Meléndez, L. A. and Silva-Vazquez, R. 2015b. Aceite de orégano sobre la calidad de pechuga de pollos de engorda. Investigación y Ciencia 65:5-12.

Méndez Zamora, G.; Durán Meléndez, L. A.; Hume, M. E. and Silva Vázquez, R. 2017. Performance, blood parameters, and carcass yield of broiler chickens supplemented with Mexican oregano oil. Revista Brasileira de Zootecnia 46:515-520.

Mohiti-Asli, M. and Ghanaatparast-Rashti, M. 2015. Dietary oregano essential oil alleviates experimentally induced coccidiosis in broilers. Preventive Veterinary Medicine 120:195-202.

Nanekarani, S.; Goodarzi, M. and Heidari, M. 2012. The effect of different levels of spearmint (Mentha Spicata) extract on immune system and blood parameters of broiler chickens. APCBEE Procedia 4:135-139.

NOM-033-SAG/ZOO-2014. 2014. Norma Oficial Mexicana. Métodos para dar muerte a los animales domésticos y silvestres. $<$ http://www.economia-noms.gob.mx/noms/consultasAction.do>. Accessed on: March 20, 2017.

NOM-062-ZOO-1999. 1999. Norma Oficial Mexicana, especificaciones técnicas para la producción, cuidado y uso de animales de laboratorio. <http://www.economia-noms.gob.mx/ noms/consultasAction.do>. Accessed on: March 20, 2017.

NRC - National Research Council. 1994. Nutritional requirements of poultry. 9th ed. National Academy Press, Washington, DC.

Park, J. H.; Kang, S. N.; Chu, G. M. and Jin, S. K. 2014. Growth performance, blood cell profiles, and meat quality properties of broilers fed with Saposhnikovia divaricata, Lonicera japonica, and Chelidonium majus extracts. Livestock Science 165:87-94. 
Peng, Q. Y.; Li, J. D.; Li, Z.; Duan, Z. Y. and Wu, Y. P. 2016. Effects of dietary supplementation with oregano essential oil on growth performance, carcass traits and jejunal morphology in broiler chickens. Animal Feed Science and Technology 214:148-153.

Reyer, H.; Zentek, J.; Männer, K.; Youssef, I. M. I.; Aumiller, T.; Weghuber, J.; Wimmers, K. and Mueller, A. S. 2017. Possible molecular mechanisms by which an essential oil blend from star anise, rosemary, thyme, and oregano and saponins increase the performance and ileal protein digestibility of growing broilers. Journal of Agricultural and Food Chemistry 65:6821-6830.

Rivero-Cruz, I.; Duarte, G.; Navarrete, A.; Bye, R.; Linares, E. and Mata, R. 2011. Chemical composition and antimicrobial and spasmolytic properties of Poliomintha longiflora and Lippia graveolens essential oils. Journal Food Science 76:C309-C317.

Roofchaee, A.; Irani, M.; Ebrahimzadeh, M. A. and Akbari, M. R. 2011. Effect of dietary oregano (Origanum vulgare L.) essential oil on growth performance, cecal microflora and serum antioxidant activity of broiler chickens. African Journal of Biotechnology 10:6177-6183.

Sharifi, S. D.; Khorsandi, S. H.; Khadem, A. A.; Salehi, A. and Moslehi, H. 2013. The effect of four medicinal plants on the performance, blood biochemical traits and ileal microflora of broiler chicks. Veterinarski Archiv 83:69-80.

Silva Vázquez, R; Durán Meléndez, L. A.; Santellano Estrada, E.; Rodríguez Muela, C.; Villalobos Villalobos, G.; Méndez Zamora G. and Hume, E. M. 2015. Performance of broiler chickens supplemented with Mexican oregano oil (Lippia berlandieri Schauer). Revista Brasileira de Zootecnia 44:283-289.

Silva-Vazquez, R.; Duran-Melendez, L. A.; Méndez-Zamora, G.; Santellano, E. S.; Xie, M.; Dunford, T. N. and Goad, C. 2017. Antioxidant activity of essential oils from various Mexican oregano ecotypes and oil fractions obtained by distillation. JSM Chemistry 5(3):1046.

Starčević, K.; Krstulović, L.; Brozić, D.; Mauri, M.; Stojević, Z.; Mikulec, Ž.; Bajić, M. and Mašek, T. 2015. Production performance, meat composition and oxidative susceptibility in broiler chicken fed with different phenolic compounds. Journal of the Science of Food and Agriculture 95:1172-1178.

Sun, Q. J.; Liu, D.; Guo, S. S.; Chen, Y. X. and Guo, Y. M. 2015. Effects of dietary essential oil and enzyme supplementation on growth performance and gut healthof broilers challenged by Clostridium perfringens. Animal Feed Science and Technology 207:234-244.

Vazquez, S. R. and Dunford, N. T. 2005. Bioactive components of Mexican oregano oil as affected by moisture and plant maturity. Journal of Essential Oil Research 17:668-671.

Wang, Z. and Goonewardene, L. A. 2004. The use of MIXED models in the analysis of animal experiments with repeated measures data. Canadian Journal of Animal Science 84:1-11.

Zhai, H.; Liu, H.; Wang, S.; Wu, J. and Kluenter, A. M. 2018. Potential of essential oils for poultry and pigs. Animal Nutrition Journal. https://doi.org/10.1016/j.aninu.2018.01.005 